\title{
Potential policy impacts: Establishment of Indonesian mining state-owned holding company
}

\author{
Chandra Wijaya ${ }^{1 *}$, Rina Andriani ${ }^{2}$ \\ Magister Administrasi dan Kebijakan Publik, Fakultas Ilmu Administrasi \\ Univeristas Indonesia \\ Email: wijayachandra@yahoo.com ${ }^{1}$, rina.andriani@ui.ac.id ${ }^{2}$
}

(Received: May 15-2019; revised: Juny 10-2019; published: December 31-2019)

\begin{abstract}
Government of Republic of Indonesia has been working to establish and operate the State-Owned Holding Company for Mining sector. There has been a long debate in whether in public, government institution, even in the industry on how this policy would give impact to all stakeholders within the business. While this mining state-owned holding company keep going on its mission to achieve the policy's objectives, in order to monitor the track we are at, this paper is trying to observe on the potential policy impacts and how can we manage to solve any damage, if there is any, so that the negative implications from the policy can be understood better and well handled by the government as well as the holding.
\end{abstract}

Keywords: mining sector; policy impact; public policy; state-owned enterprises; state-owned holding company.

\section{INTRODUCTION}

The Government of the Republic of Indonesia through the Ministry of State-Owned Enterprises (BUMN) acts and is authorized to handle policies surrounding the management of State-Owned Enterprises (Hermawan \& Adinda, 2012; Warganegara, Hutagaol, Saputra, \& Anggraini, 2013; Wicaksono, 2009). BUMN is often understood as a line of important contributors in managing the economic system in Indonesia. For this reason, every decision taken will be able to influence other economic chain conditions starting from the private sector to abroad. In connection with this, State-owned Enterprises (SOEs) also play a role in determining the course of the economy, especially in stimulating growth in the field of industry, diluting opportunities and job vacancies, business and business potential to strengthen the state budget condition through achieving the economy as tax and non-tax revenues (Du, Tang, \& Young, 2012; Menozzi, Gutiérrez Urtiaga, \& Vannoni, 2011; Wei \& Wang, 1997).

Then, SOEs also have a role in the supply and supply of goods and services as public needs where these needs have not been fulfilled by the private sector (Alford, 2002; Essig \& Batran, 2005; Fountain, 2001; Karnani, 2007). The strategic role concerns various sectors such as the economy, banking and non-banking finance, manufacturing, agriculture, electricity, transportation, construction, telecommunications and others. As an upstream industry, the performance of BUMNs will influence the level of efficiency of the industry below (Siahaan, 2005). 


\section{4 |Jurnal Ilmiah Ilmu Administrasi Publik: Jurnal Pemikiran dan Penelitian Administrasi Publik Volume 9 Number 2,July - December 2019. Page 213-224}

BUMN represents State ownership. In its operational activities, BUMN is bound by various regulations attached to it as part of the company or public company. While in terms of management of State Assets, for BUMN, through Government Regulation Number: 228 in 2001, then Government Regulation number 64 was issued in the same year regarding the position, duties and authority of the General Meeting of Shareholders (GMS) or shareholders in Company.

The task of the Ministry of BUMN is to assist the president in formulating and formulating policies and coordinating BUMN governance. The following is an explanation of the functions of the Ministry of BUMN:

a) Formulate government policies in the field of fostering and managing BUMN and include controlling activities, privatization, increasing efficiency and restructuring or reorganizing BUMN;

b) Coordinate and improve the preparation and integration of the program plan, analysis, monitoring and review and evaluation in the field of SOE guidance and governance;

c) Submitting a report which is the result of the evaluation above, including suggestions and considerations in terms of developing BUMN.

In the process of carrying out its duties and functions, the existence of the Ministry of BUMN refers to the State Policy Outline as follows:

a) Carrying out efficient, transparent and professional SOE arrangements, especially for BUMNs whose businesses are related to the public interest and related to the implementation of public, industrial, security and defense facilities and managing assets which are considered strategically followed by other business activities that are not carried out by the private sector;

b) Carry out the development of cooperative relations in the form of mutually beneficial business ties between corporations, the private sector and also state-owned enterprises which include large-scale businesses, the middle and small classes in the mission of strengthening the structure and resilience of the national economy;

c) Healthy SOEs, especially those whose business is related to the public interest of SOEs and not related to the public interest, are driven towards privatization-based management through the capital market.

Based on Law Number 19 of 2003 which was then processed by Toto (2017), the role of BUMN can be described as follows: 


\begin{tabular}{|c|c|c|c|c|c|}
\hline & $\begin{array}{l}\text { National } \\
\text { Economic } \\
\text { Growth }\end{array}$ & $\begin{array}{l}\text { Financial } \\
\text { Objectives }\end{array}$ & $\begin{array}{l}\text { Public } \\
\text { Services }\end{array}$ & $\begin{array}{l}\text { Entrepreneur- } \\
\text { ship }\end{array}$ & $\begin{array}{l}\text { Development of } \\
\text { Weak Economy, } \\
\text { Corporation and } \\
\text { Communities }\end{array}$ \\
\hline Activity & $\begin{array}{l}\text { - Infrastructure } \\
\text { - Energy } \\
\text { - Funding/ Credit }\end{array}$ & $\begin{array}{l}\text { - Infrastructure } \\
\text { - Energy } \\
\text { Funding/ } \\
\text { Credit }\end{array}$ & $\begin{array}{l}\text { - Fuel oil } \\
\text { - Electricity } \\
\text { - Transportat } \\
\text { ion } \\
\text { - Agricultural } \\
\text { Facilities } \\
\text { - Foodstuffs } \\
\text { - Health }\end{array}$ & $\begin{array}{l}\text { Transportation } \\
\text { (facilities and } \\
\text { infrastructure) }\end{array}$ & $\begin{array}{l}\text { - Credit guarantee } \\
\text { - Partnerships and } \\
\text { community } \\
\text { development } \\
\text { program (PKBL) } \\
\text { - SME loans }\end{array}$ \\
\hline $\begin{array}{l}\text { SOE } \\
\text { Sectors }\end{array}$ & $\begin{array}{l}\text { - Ports, } \\
\text { Airports, Roads } \\
\text { - Fuel oil, } \\
\text { electricity, coal } \\
\text { - Banking and } \\
\text { Financial } \\
\text { Services }\end{array}$ & $\begin{array}{l}\text { - Banking, } \\
\text { Telecommunic } \\
\text { ations \& Trade } \\
\text { - Mining } \\
\text { - Plantation }\end{array}$ & $\begin{array}{l}\text { - Energy } \\
\text { - Transportat } \\
\text { ion } \\
\text { - Agricultural } \\
\text { Facilities } \\
\text { - Logistics } \\
\text { - Pharmacy } \\
\text { - Insurance }\end{array}$ & Transportation & $\begin{array}{l}\text { - Guarantee } \\
\text { - Banking } \\
\text { - All SOEs are } \\
\text { profitable }\end{array}$ \\
\hline Indicators & $\begin{array}{l}\text { - Increased SOE } \\
\text { spending \& } \\
\text { investment } \\
\text { - Availability of } \\
\text { Economic } \\
\text { Infrastructure } \\
\text { Facilities }\end{array}$ & $\begin{array}{l}\text { - Increased } \\
\text { Operating } \\
\text { Income \& } \\
\text { Dividends } \\
\text { - Increased } \\
\text { capitalization } \\
\text { of BUMN } \\
\text { shares in the } \\
\text { capital market }\end{array}$ & $\begin{array}{l}\text { Availability } \\
\text { of goods \& } \\
\text { services with } \\
\text { the right } \\
\text { amount and } \\
\text { affordable } \\
\text { prices }\end{array}$ & $\begin{array}{l}\text { Increased role } \\
\text { of SOEs in } \\
\text { Regional } \\
\text { Development }\end{array}$ & $\begin{array}{l}\text { Increased role of } \\
\text { SOEs in the } \\
\text { economy }\end{array}$ \\
\hline
\end{tabular}

\section{Figure 1}

The role of SOEs in accordance with Article 2 of Law No. 19 of 2003

Source: Ministry of BUMN, data processed by Toto (2017)

The mining industry is one of the industrial sectors that has a large contribution to Indonesia starting from increasing export revenues, regional development, increasing economic activity, opening employment and income sources to the central budget and regional budgets. Based on data from the Ministry of Finance, currently non-tax state revenue (PNPB) from the mineral and coal sector reaches 75 percent to 80 percent of the total PNPB. Recorded, the nontax revenues from the mining sector until December 2018 reached Rp 46.6 trillion or 146\% of the target set at Rp 32.1 trillion.

BUMN Mining Holding officially formed on November 29, 2017. The process of establishing Mining BUMN Holding is carried out through the following process: 
216 Jurnal Ilmiah Ilmu Administrasi Publik: Jurnal Pemikiran dan Penelitian Administrasi Publik Volume 9 Number 2,July - December 2019. Page 213-224

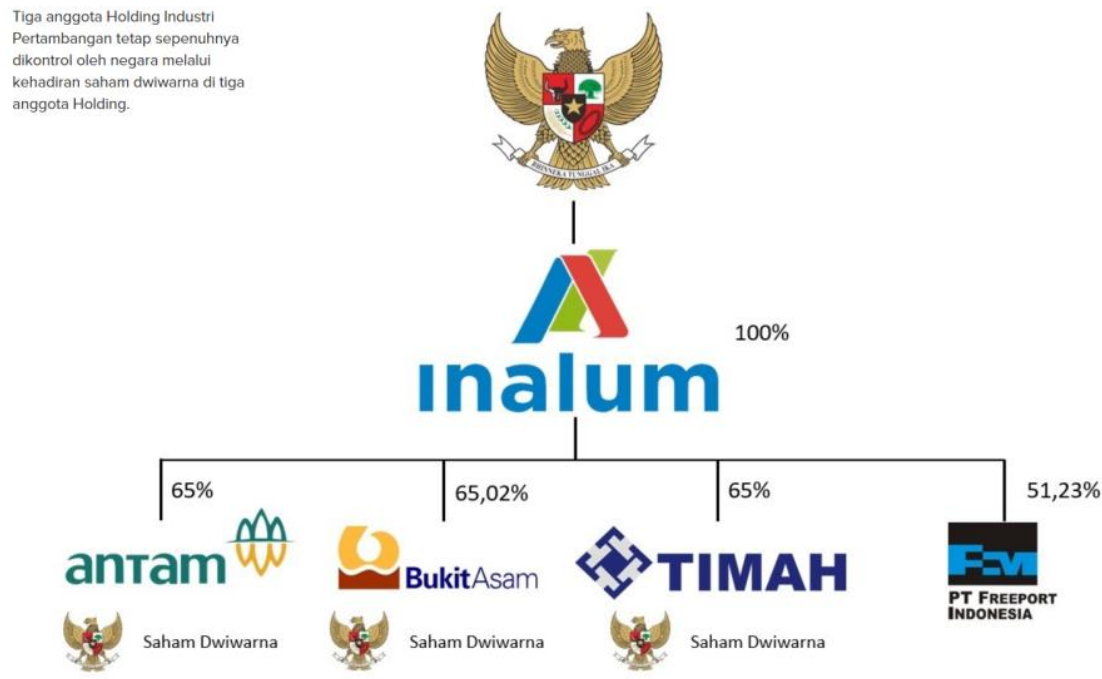

Figure 2

Indonesian State-owned Mining Holding Company - Ownership Structure

Source: $\underline{w w w . i n a l u m . c o m}$

The establishment of the Indonesian State-Owned Mining Holding company is expected to achieve several goals as follows: a) Control mineral reserves; b) Run the program of the downstream and local content; c) Make the mining SOEs as one of the world-class companies. Taking into account the exposure to the role of the BUMN, then it will be discussed about how the restructuring process is through the establishment of BUMN Holding, including the potential analysis of its impact on holding members. What is the potential policy impacts of the establishment of the Indonesian mining state-owned holding company? How to deal with the initial implications so that the main objectives of the policy can be achieved? The findings and discussions session will elaborate these questions further.

\section{METHOD}

The object of this research is financial performance, three members of the Indonesian mining holding company under PT Indonesia Asahan Alumunium namely PT Antam Tbk, PT Timah Tbk, and PT Bukit Asam Tbk. The period under study covers the years 2017-2019 in the first quarter by taking into account the formation time of state-owned holding companies so that financial performance can be known several years before and after holding. With the period covered, the analysis of the effect of holding only includes short-term effects.

Quantitative data is obtained from secondary sources (Creswell \& Creswell, 2017), namely from the financial statements of the BUMN company that are downloaded from the site of each BUMN. In addition, other data is obtained from the stock site which includes information relating to these companies. 
The dependent variable in this study is the financial performance of SOEs as measured by Financial performance, Corporate governance, Operational efficiency, and Joint projects among sub-holdings. The indicators used for the financial performance are the value of Return on Assets (ROA) and Earnings Per Share (EPS).

As for the Corporate governance, the writer will observe on how this policy creates an impact to the sub's corporate governance. This observation will be conducted by analyzing the value of each company's rate of Good Corporate Governance (GCG) after the establishment of Holding company.

\section{RESULT AND DISCUSSION}

As per the end of November 2017, the Government of Indonesia had at last officially established the Indonesian State-owned Mining Holding Company. This action is a follow up item from the issuance of Government Regulation (PP) Number 47/2017 concerning the Addition of State Capital Participation (PNM) to PT Inalum's Shares issued on 14 November 2017.

In the past year from the implementation of the policy, several implications are believed to occur in the holding environment, especially the members of the holding. According to Anderson (1984), in order to analyze the impact of implemented policy, we shall have in mind, the distinction between policy outputs and policy outcomes. Policy outputs are things governments do, for example, arrests for burglary, highway construction, operation of public schools, or payment of welfare benefits. These activities may be measured by such arrests for burglary per 100,000 population, standards as per capita highway expenditures, per pupil school expenditures, per capita welfare expenditure, and the like. Such figures tell us little about the outcomes, or impacts, of public policies because, in trying to determine policy outcomes, our concern is with the changes in the environment or political system caused by policy action. The impact of a policy has several dimensions, all of which must be taken into account in the course of evaluation. These include: the impact on the public problem at which it is directed and on the people involved, policies may have effects on situation or group other than those at which they are directed, policies may have impacts on future as well as current conditions, the direct costs of policies, and indirect costs that are experienced by the community or some of its members.

Referring to the all 5 dimensions mentioned above, writer has observed those implications and divided them into 4 aspects which consisted of: Financial performance, Corporate governance, Operational efficiency, and Joint projects among sub-holdings. 
218 Jurnal Ilmiah Ilmu Administrasi Publik: Jurnal Pemikiran dan Penelitian Administrasi Publik Volume 9 Number 2,July - December 2019. Page 213-224

\section{Financial Performance}

In the same week of the official announcement that the mining state-owned holding company will be formally established, shares of PT Antam, PT Timah and PT Bukit Asam dropped $2.9 \%, 1.1 \%$ and $4.8 \%$, respectively, at the close of trading on Wednesday during the announcement -- sharper than the benchmark Jakarta Composite Index's 0.27\% decline. This finding is somewhat interesting to elaborate to get a bigger picture on how this policy can impact the holding subs financially.

Based on value-increasing theory, mergers are carried out in order to produce synergies between companies so as to increase the value of the company. With the efficiency process, if a merger is carried out, value-creation with positive returns are expected to occur for each company (Akpan, Wanke, Chen, \& Antunes, 2019; Alexandridis, Antypas, \& Travlos, 2017; Banerjee \& Eckard, 1998). This is especially seen from the value of Return On Assets (ROA).

\section{Table 1}

ROA Growth of Indonesian State-owned Mining Holding Company's Members

\begin{tabular}{lllll}
\hline Details & $\mathbf{2 0 1 7}$ & $\mathbf{2 0 1 8}$ & $\mathbf{2 0 1 9}$ (quarter I) & Industry \\
\hline PT Antam Tbk & $0.45 \%$ & $0.74 \%$ & $0.51 \%$ & $-1.93 \%$ \\
PT Timah Tbk & $4.23 \%$ & $3.51 \%$ & $1.68 \%$ & $0.16 \%$ \\
PT Bukit Asam Tbk & $20.68 \%$ & $21.19 \%$ & $4.63 \%$ & $0.88 \%$ \\
\hline
\end{tabular}

Source: Processed data from corporate's financial statement (2018-2019Q1)

Basically, the ROA told us about how a company could make out of profit over assets they do have. A high number of ROA provides a higher value of company's capabilities to efficiently operate its business. And it's safe enough to say, each industry have their own standard of ROA, according to the differences between one and another in using company's assets in order to gain profits (Muhammad, Rehman, \& Waqas, 2016; Purnamasari, 2015).

Back to the table. In the last one year since the establishment of Indonesian mining state-owned holding company with PT Inalum as the holding of its subs- PT Antam, PT Timah and PT Bukit Asam, we can observe that both Antam and Bukit Asam has increased the number of Return on Assets. In 2017, PT Antam's ROA was at $0.45 \%$, reached $0.74 \%$ in 2018, and was at 0.51 by the end of the first quarter of 2019. PT Bukit Asam's ROA in 2018 was $21.19 \%$ which previously at $20.68 \%$ in 2017, and reportedly was at $4.63 \%$ by the end of March 2019. It might be quite early to say that the increased number is a result of the acquisition of the companies by the holding. However, it is important to understand that the five years average of PT Antam's ROA was at $-0.79 \%$, while the five years average of standard ROA in the industry was 3.3\%. This increase shall be a good start for PT Antam to keep on going with its ROA growth to show its effectivity in managing assets to get more profits. Different situation happens to PT Bukit Asam. The five years average ROA was strong compared to the average in the industry, $17.28 \%$ compared to $6.2 \%$.

In the other hand, PT Timah's ROA was decreased from $4.23 \%$ in 2017 to $3.51 \%$ in 2018 , and $0.51 \%$ in the end of the first quarter of 2019. The decrease in ROA of state-owned holding 
indicated that the contribution of state-owned holding to state revenues was not optimal. The government established a state-owned holding with the aim that SOEs engaged in the same business sector can work together to achieve optimal profits. It turns out that these objectives based on the data in Table 1 have not been relatively achieved, at least when measured by profitability ratios in the form of ROA. Thus, an analysis is needed to determine the impact of restructuring through BUMN holding on the financial performance of SOEs.

In addition to the ROA calculation, the data on the Earnings per share (EPS) will be also provided. The EPS rating is one of reliable key when a shareholder is picking the best and most favorable stocks. This information is calculated by dividing a company's net income by its number of shares outstanding. For more details, the Table 2 below reflects the number of Holding members' EPS for the past year until the most recent quarter.

Table 2

EPS of Indonesian State-owned Mining Holding Company's Members

\begin{tabular}{|c|c|c|c|c|}
\hline Details & $\begin{array}{c}E P S(M R Q) \text { vs } Q 1 \\
2018\end{array}$ & Industry & $\begin{array}{c}\text { EPS TTM vs } \\
\text { TTM } 2018\end{array}$ & Industry \\
\hline PT Antam Tbk & $-30.12 \%$ & $53.29 \%$ & $113.13 \%$ & $-10.26 \%$ \\
\hline PT Timah Tbk & $440.2 \%$ & $-593.49 \%$ & $65 \%$ & $-99.09 \%$ \\
\hline PT Bukit Asam Tbk & $-21.82 \%$ & $23.53 \%$ & $-6.97 \%$ & $-15.98 \%$ \\
\hline
\end{tabular}

Source: Processed data from corporate's financial statement (2018-2019Q1)

Notes

MRQ: Most Recent Quarter

TTM: Trailing Twelve Months

Referring to investors.com, it is said that stocks with EPS growth rates of at least $25 \%$ with the previous year levels reflect a company has services or products in very strong demand. From the Table 2 we can see that. This observation through the statistic on the number of company's ROA, shall provide us with initial understanding on how the establishment of the Indonesian mining state-owned holding company may created impact to its subs. The next observation will be based on the corporate governance of the holding and its subs.

\section{Corporate Governance}

According to Kim (2018), currently, State-owned enterprises that have been partially privatized are the largest companies in their respective industries, including mining. PT Antam as nickel producer, PT Timah as tin miner and PT Bukit Asam as coal producer. On the other hand, smaller state-owned enterprises with limited expected benefits from privatization have largely remained fully owned by the government. In this situation, the balance of power is expected to be carried by the subsidiaries, leading to a situation where "children control their parents," and the holding's coordinating capacity will be limited. Moreover, the situation will become even more complicated when the holding with limited management capacity must deal with larger SOEs' minority private shareholders. 
220 Jurnal Ilmiah Ilmu Administrasi Publik: Jurnal Pemikiran dan Penelitian Administrasi Publik

Volume 9 Number 2,July - December 2019. Page 213-224

Therefore, in this section, the writer will observe on how this policy creates an impact to the sub's corporate governance. This observation will be conducted by analyzing the value of each company's rate of Good Corporate Governance (GCG) after the establishment of Holding company.

As for PT Antam, since 2004, ANTAM has appointed an independent assessor to assess the GCG implementation. In accordance with regulatory developments related to GCG implementation, in 2018 the Board of Commissioners of ANTAM has appointed PT RSM Indonesia, an independent assessor to conduct assessment and implementation of GCG in ANTAM with 3 (three) methods of assessment in accordance with SK-16/S.MBU/2012 on Assessment and Evaluation Indicators or Parameters for the Implementation of Good Corporate Governance in State-Owned Enterprise, parameters from ASX Corporate Governance Principles \& Recommendations 3rd Edition, and the ASEAN Corporate Governance Scorecard v.2.0 recently released in May 2017 by ASEAN Market Capital Forum (ACMF). Assessment on GCG Implementation in ANTAM is also conducted in accordance with the scorecard defined by the SOE Ministry in the SK-16/S.MBU/2012 dated June 6, 2012 on Assessment and Evaluation Indicator or Parameter of GCG Implementation within SOE. The followings are the result of the GCG assessment of PT Antam for the last there years.

Table 3

Achievement of ANTAM's GCG Implementation

\begin{tabular}{|c|c|c|c|}
\hline PARAMETER & ASSESSOR & $\begin{array}{l}\text { ACHIEVEMENT } \\
\text { OF } 2016\end{array}$ & $\begin{array}{l}\text { ACHIEVEMENT } \\
\text { OF } 2017\end{array}$ \\
\hline $\begin{array}{l}\text { Corporate Governance Perception } \\
\text { Index (CGPI) }\end{array}$ & $\begin{array}{l}\text { Indonesian Institute } \\
\text { of Corporate } \\
\text { Governance (IICG) }\end{array}$ & 88,64 & 88,69 \\
\hline $\begin{array}{l}\text { ASEAN Corporate Governance } \\
\text { Scorecard }\end{array}$ & $\begin{array}{l}\text { Indonesia Institute } \\
\text { for Corporate } \\
\text { Directorship }\end{array}$ & 90,29 & 95,87 \\
\hline BUMN Scorecard, SK-16/S-MBU/2012 & $\begin{array}{l}\text { PT Sinergi Daya } \\
\text { Prima }\end{array}$ & 97,86 & 97,01 \\
\hline $\begin{array}{l}\text { Australian Securities Exchange (ASX) } \\
\text { Corporate Governance Principles and } \\
\text { Recommendations }\end{array}$ & $\begin{array}{l}\text { PT Sinergi Daya } \\
\text { Prima }\end{array}$ & 4,76 & $\begin{array}{r}\text { The Corporate } \\
\text { Structure is } \\
\text { Outstanding }\end{array}$ \\
\hline $\begin{array}{l}\text { Corporate Govermance Guidelines for } \\
\text { Public Company by Financial Services } \\
\text { Authority }\end{array}$ & $\begin{array}{l}\text { PT Sinergi Daya } \\
\text { Prima }\end{array}$ & Fully Comply & Fully Comply \\
\hline
\end{tabular}

Source: PT Antam's Website (www.antam.com) 
The GCG Implementation assessment conducted for Antam in 2018 based on BUMN scorecard was 97.01 or "Very Good", based on the ASX Corporate Governance Principles 3rd Edition was 27 of 29 or equal to $93.11 \%$ with Recommendations Fulfilled as "Very Good" and Based on Implementation ASEAN Corporate Governance Scorecard, the fulfillment rate was $84.07 \%$.

The followings are the achievement records for the last three years from PT Timah.

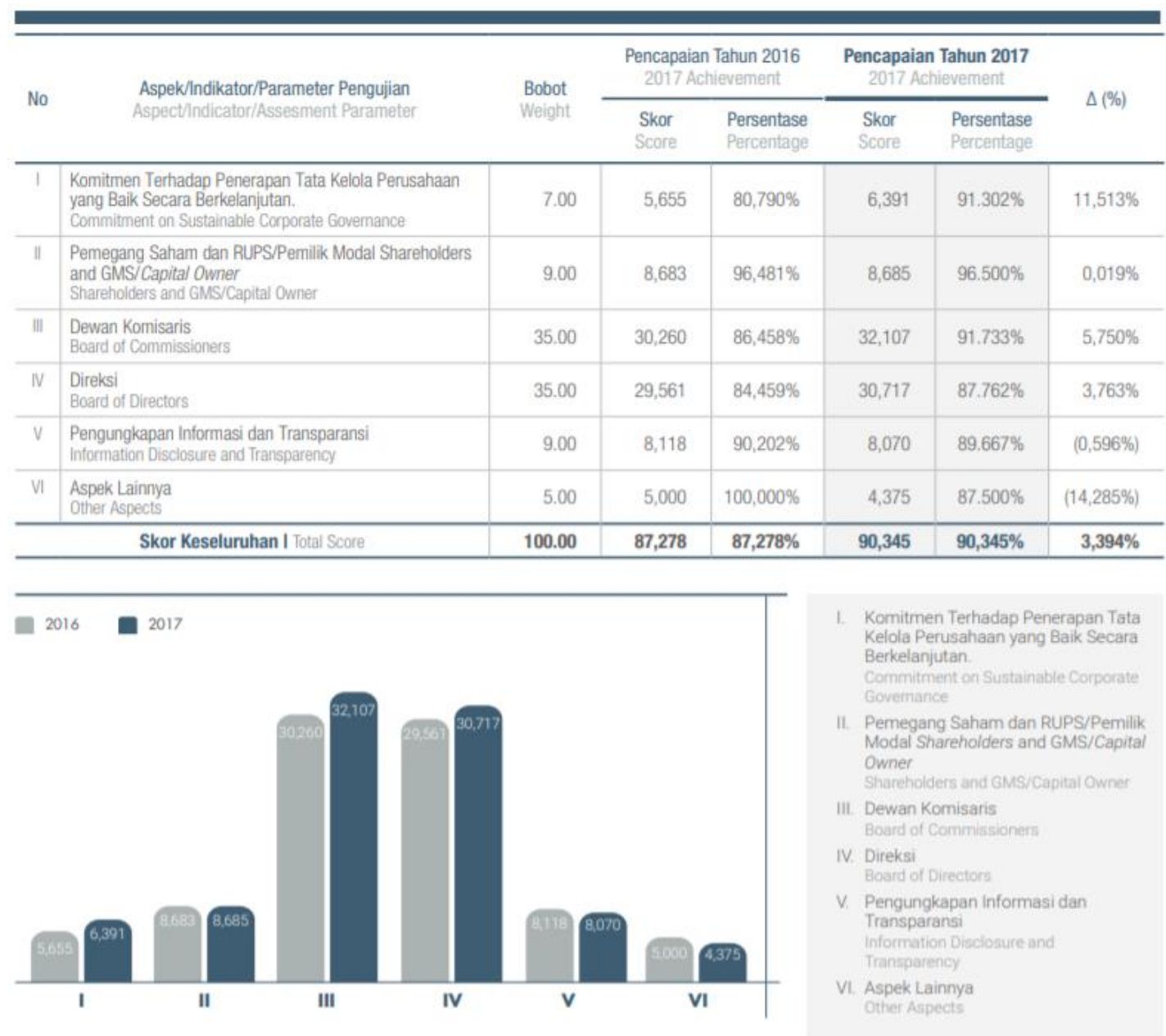

Figure 3

PT Timah's achievements in the implementation of GCG practices (2017)

Source: PT Timah Annual Report 2017 
222 |Jurnal Ilmiah Ilmu Administrasi Publik: Jurnal Pemikiran dan Penelitian Administrasi Publik Volume 9 Number 2,July - December 2019. Page 213-224

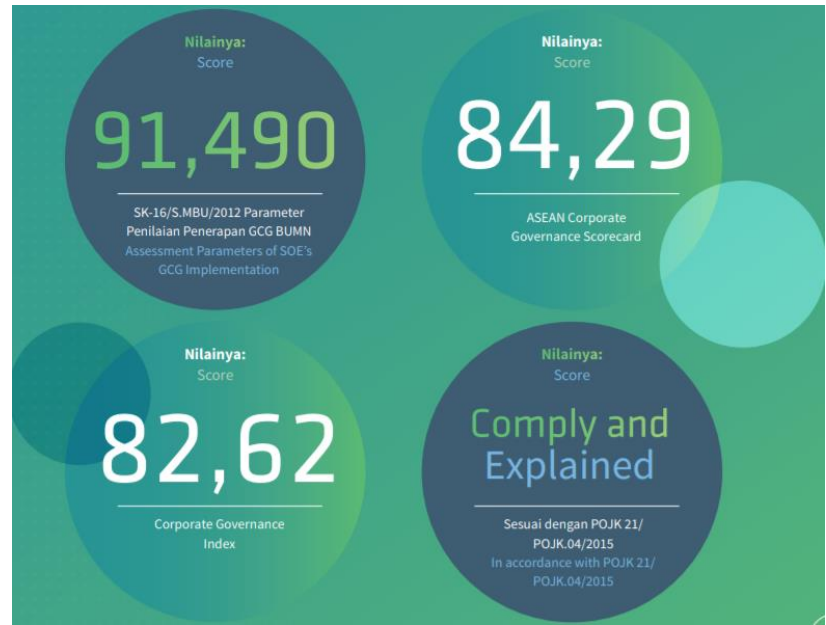

Figure 4

PT Timah's achievements in the implementation of GCG practices (2018) Source: PT Timah Annual Report 2018

And as for PT Bukit Asam, the followings are the result of its GCG assessment for the last three years.

Table 4 GCG Assessment of PT Bukit Asam (2017)

\begin{tabular}{|c|c|c|c|c|c|c|c|}
\hline \multirow{3}{*}{ No } & \multirow{3}{*}{ Aspek Penilaian / Assessment Aspect } & \multicolumn{3}{|c|}{ Self Assessment } & \multicolumn{3}{|c|}{$\begin{array}{l}\text { Assessment PT Sinergi Daya } \\
\text { Prima / Assessment by PT } \\
\text { Sinergi Daya Prima }\end{array}$} \\
\hline & & \multirow{2}{*}{$\begin{array}{l}\text { Bobot / } \\
\text { Point }\end{array}$} & \multicolumn{2}{|c|}{$\begin{array}{l}\text { Capaian tahun } 2017 \\
\text { / Achievement in } \\
2017\end{array}$} & \multirow{2}{*}{$\begin{array}{c}\text { Bobot / } \\
\text { Point }\end{array}$} & \multicolumn{2}{|c|}{$\begin{array}{l}\text { Capaian Tahun } \\
2016 \text { / Achievement } \\
\text { in } 2016\end{array}$} \\
\hline & & & $\begin{array}{l}\text { Skor / } \\
\text { Score }\end{array}$ & $\%$ & & $\begin{array}{l}\text { Skor / } \\
\text { Score }\end{array}$ & $\%$ \\
\hline 1 & $\begin{array}{l}\text { Komitmen terhadap Penerapan Tata Kelola Secara } \\
\text { Berkelanjutan / Commitment to Sustainable } \\
\text { Corporate Governance Implementation }\end{array}$ & 9 & 5,853 & $83,61 \%$ & 9 & 5,940 & $84,86 \%$ \\
\hline 2 & $\begin{array}{l}\text { Pemegang Saham dan RUPS / Shareholders and } \\
\text { GMS }\end{array}$ & 9 & 8,852 & $98,35 \%$ & 9 & 8,549 & $94,99 \%$ \\
\hline 3 & Dewan Komisaris / Board of Commissioners & 35 & 30,383 & $86,82 \%$ & 35 & 29,766 & $85,05 \%$ \\
\hline 4 & Direksi / Board fo Directors & 35 & 32,796 & $93,70 \%$ & 35 & 31,645 & $90,41 \%$ \\
\hline 5 & $\begin{array}{l}\text { Pengungkapan Informasi dan Transparansi / } \\
\text { Information Disclosure and Transparency }\end{array}$ & 9 & 8,195 & $91,05 \%$ & 9 & 7,940 & $88,23 \%$ \\
\hline 6 & Aspek Lainnya / Other Aspects & 5 & 4,810 & $96,00 \%$ & 5 & 4,821 & $96,00 \%$ \\
\hline \multicolumn{2}{|c|}{ Total } & 100 & & $90,88 \%$ & \multicolumn{2}{|c|}{100} & $88,66 \%$ \\
\hline
\end{tabular}

Source: Annual Report of PT Bukit Asam (2017) 
The result of GCG for the year 2018 is not available (in numbers) in PT Bukit Asam's Annual Report 2018. This shall be taken into account that such management capacities and capabilities is important to take a whole role as GCG is one of key factor to determine a company's overall performance.

\section{CONCLUSION}

All in all, the implications we can observe from the establishment of the Indonesian mining state-owned holding company are first, the Financial performance where we could see there's trust issue from the minority shareholders within the implementation of the policy temporarily. However, at some point, the financial performance through the value of ROA and EPS show cast a good sign for the long-term growth for the company. Even though one of the holding members - PT Bukit Asam - is not currently in its best condition after the establishment of the mining SOHC.

\section{REFERENCES}

Akpan, M., Wanke, P., Chen, Z., \& Antunes, J. M. (2019). Unveiling the Endogenous Relationship Between Technical Efficiency and Value Creation in Mergers and Acquisitions in Nigeria. South African Journal of Economics.

Alexandridis, G., Antypas, N., \& Travlos, N. (2017). Value creation from M\&As: New evidence. Journal of Corporate Finance, 45, 632-650.

Alford, J. (2002). Defining the client in the public sector: A social-exchange perspective. Public Administration Review, 62(3), 337-346.

Banerjee, A., \& Eckard, E. W. (1998). Are mega-mergers anticompetitive? Evidence from the first great merger wave. The Rand Journal of Economics, 803-827.

Creswell, J. W., \& Creswell, J. D. (2017). Research design: Qualitative, quantitative, and mixed methods approaches. Sage publications.

Du, F., Tang, G., \& Young, S. M. (2012). Influence activities and favoritism in subjective performance evaluation: Evidence from Chinese state-owned enterprises. The Accounting Review, 87(5), 1555-1588.

Essig, M., \& Batran, A. (2005). Public-private partnership-Development of long-term relationships in public procurement in Germany. Journal of Purchasing and Supply Management, 11(5-6), 221-231.

Fountain, J. E. (2001). Paradoxes of public sector customer service. Governance, 14(1), 55-73.

Hermawan, A. A., \& Adinda, G. (2012). The effect of board characteristics and audit committee existence on earnings quality of Indonesian state-owned enterprises. Available at SSRN 2135051. 
224 Jurnal Ilmiah Ilmu Administrasi Publik: Jurnal Pemikiran dan Penelitian Administrasi Publik Volume 9 Number 2,July - December 2019. Page 213-224

Karnani, A. (2007). The mirage of marketing to the bottom of the pyramid: How the private sector can help alleviate poverty. California Management Review, 49(4), 90-111.

Kim, B. (2018). Is Narcissism Sustainable in CEO Leadership of State-Owned Enterprises? Sustainability, 10(7), 2425.

Menozzi, A., Gutiérrez Urtiaga, M., \& Vannoni, D. (2011). Board composition, political connections, and performance in state-owned enterprises. Industrial and Corporate Change, 21(3), 671-698.

Muhammad, H., Rehman, A. U., \& Waqas, M. (2016). The relationship between working capital management and profitability: A case study of tobacco industry of Pakistan. The Journal of Asian Finance, Economics and Business (JAFEB), 3(2), 13-20.

Purnamasari, D. (2015). The effect of changes in return on assets, return on equity, and economic value added to the stock price changes and its impact on earnings per share. Research Journal of Finance and Accounting, 6(6), 80-90.

Siahaan, R. (2005). BUMN Indonesia: isu, kebijakan, dan strategi. Elex Media Komputindo.

Warganegara, D. L., Hutagaol, Y. R. I., Saputra, M. A., \& Anggraini, Y. (2013). State-Owned Enterprises and Corporate Governance Strength: Evidence from Indonesia. International Journal of Management and Business Research, 3(4), 325-335.

Wei, S.-J., \& Wang, T. (1997). The Siamese twins: do state-owned banks favor state-owned enterprises in China? China Economic Review, 8(1), 19-29.

Wicaksono, A. (2009). Corporate governance of state-owned enterprises: investment holding structure of government-linked companies. University of St. Gallen. 